\title{
Comparative Study of the Shelf Life of Ready to Eat and Shelf Stable Meat Pickle Prepared from Spent Duck, Chicken and Turkey Meat
}

\author{
Abadhut Dey ${ }^{1 *}$, Saurabh Karunamay ${ }^{2}$, Subhasish Biswas ${ }^{1}$, Debasish Bhattacharya ${ }^{1}$, \\ Gopal Patra ${ }^{1}$ and Sudip Kumar Das ${ }^{3}$ \\ ${ }^{1}$ Department of Livestock Products Technology, ${ }^{3}$ Director of Research, DREF, WBUAFS, \\ Kolkata, West Bengal, India \\ ${ }^{2}$ Department of Livestock Products Technology, FVAS, BHU, Mirzapur, Uttar Pradesh, India \\ *Corresponding author
}

\section{A B S T R A C T}

An experiment was under taken to study the processing of shelf stable intermediate moisture type duck, chicken and turkey meat pickle and to evaluate storage stability of pickles at ambient temperature $\left(32 \pm 2^{\circ} \mathrm{C}\right)$. The storage studies were conducted at an interval of 15days till 90 days period. Pre-cooked and fried lean minced chicken, duck and

Keywords

Meat pickle, spent chicken, Spent duck, Spent turkey, Storage stability, Quality attributes

Article Info

Accepted:

12 December 2020 Available Online: 10 January 2021 turkey meat was mixed separately with vinegar, salt, spices and condiments and packed air tight in glass jar. Average cooking yield of duck, chicken and turkey meat pickle were $59.1 \%, 57.2 \%$ and $58.8 \%$ respectively. Proximate composition, pH, TBA values, microbiological qualities and sensory qualities of the pickles were studied as per standard procedure. The mean per cent moisture, crude protein, ether extract and total ash contents of duck pickles were $36.18,17.82,39.64$, and 3.71 respectively. The mean per cent moisture, crude protein, ether extract and total ash contents of chicken pickles were 59.74, 18.56, 15.92, and 3.51 respectively. The mean per cent moisture, crude protein, ether extract and total ash contents of turkey pickles were $61.78,16.02,16.74$, and 3.28 respectively. The pathogenic bacteria like Salmonella spp., Clostridium spp., Staphylococcus spp. and E. coli were found absent in duck, chicken and turkey meat pickle during the entire storage period. The product had appreciable sensory quality and low total microbial, yeast and mould counts. The sensory scores revealed that the pickle was acceptable even up to 90 days storage. High perishability of meat either in fresh or in processed forms is serious problem in tropical countries. Now-a-days, there is need to develop the foods which are shelf-stable so that can be distributed in various locations without aid of any refrigeration. Pickling is one of the alternative solutions to develop such kind of products.

\section{Introduction}

Poultry meat and eggs are one of the most widely consumed animal origin foodstuff in a wide variety of cultures, traditions and religions across the whole world. In India, the total poultry population is 851.81 million in 2019 (20th Livestock Census Report, 2019, 
Ministry of Fisheries, Animal Husbandry \& Dairying, Govt. of India). Poultry is one of fastest growing segments of the agricultural sector in India with around $8 \%$ growth rates per annum (Chatterjee and Rajkumar, 2015). As per World Bank projection, demand for food will increase by $50 \%$ and for meat by $85 \%$ by 2030 (Guleria et al., 2015). Among other poultry birds, ducks occupy next to chicken in poultry meat production i.e. agricultural economy in India. In 2016 the duck population (Anas spp.) were reached 1.24 billion throughout the world and 1.1 billion in Asia. Asia is holding 82.2\% production of duck meat and has also the highest increase of total and of per capita duck meat by $308 \%$ and $244 \%$, respectively (Sumarmono, 2019). People consuming duck meat is due to its high nutritional value with high percentage of polyunsaturated fatty acids and balanced ratio between omega-3 fatty acids and omega-6 (Sumarmono, 2019). Spent hen and spent ducks are the by-products of layer industry. Spent ducks meat is tough, less juicy and fetches fewer prices which contribute to the economic losses in the layer poultry industry (Jayanthi, 2008). Duck meat has higher myoglobin in muscle fibers of breast muscle compared to chicken, and is considered as red meat. Moreover, due to stronger gamey flavour of duck meat and high fat content (13.8\%) it may be less appreciated by the consumer. Development and diversification of ready-to-eat duck meat products is expected to increase consumption levels to the consumers has been reported (Biswas, 2019). Shelf stable meat products like meat pickles, canned meat, cured meat and snack type meat products have been reported (Anjaneyulu, 2005). From the ancient time, Pickling is used as methods of preservation of raw materials like fruits, vegetables etc. Pickled products are very common in Indian daily diets and are much relished by common people i.e. consumers. Presently more emphasis is given on developing shelf stable ready to eat meat products which can be stored in ambient temperature. Hence, duck and turkey meat production with its physicochemical properties, processing and development of value-added ready-to-eat products is discussed in detail to explore its importance as an alternative to chicken.

\section{Materials and Methods}

The present study was conducted to identify the quality and acceptability of meat pickle prepared from spent ducks, hens and turkey birds at the Department of Livestock Products Technology, Faculty of Veterinary \& Animal Sciences, West Bengal University of Animal and Fishery Sciences, Kolkata-37, West Bengal, India. The work was carried out from June 2020 to September 2020, when the average temperature was $32 \pm 2^{\circ} \mathrm{C}$. Culled and spent ducks, hens and turkey birds were procured from the local poultry farm for the study. The birds were slaughtered by humane method, then dressed hygienically and deboned. Scientific slaughter, dressing, deboning was done in the poultry processing unit of the Department of Livestock Products Technology, West Bengal University of Animal and Fishery Sciences, Kolkata as per the standard procedure of Sahoo and Panda (1983) with slight modification. After slaughtering and dressing, the carcasses were manually deboned as per the method of Staff and Darrow (1953). Deboned meat was stored in deep freezer $\left(-18^{\circ} \mathrm{C}\right)$ for further use. Frozen meat was thawed in the refrigerator for making meat pickle. Recipe of meat pickle is presented in table. Meat pieces of about 4 sq. $\mathrm{cm}$ (approximately) were marinated in 3\% vinegar $(\mathrm{v} / \mathrm{v})$ added with pinch of turmeric and common salt for 4 hours at $4 \pm 1^{\circ} \mathrm{C}$. After marinating, meat pieces were removed from vinegar and pressure cooked $\left(1.1 \mathrm{~kg} / \mathrm{cm}^{2}\right.$ at $120^{\circ} \mathrm{C}$ ) for 10 minutes and fried in refined vegetable oil $\left(300^{\circ} \mathrm{C}\right)$ till it develops a golden 
brown colour and was kept separately. Dry spices were fried in the same oil for about one minute and broth was then added and heated with constant stirring till boiling started. Fried meat pieces were added to it and allowed to boil for 2 minutes. A top up quantity of heated and cooled refined oil was added to the pickle and it was kept for maturation for 24 hours at room temperature. The cooled meat pickle was then packed in pet bottles and stored in a dry place at room temperature $\left(32 \pm 2^{\circ} \mathrm{C}\right)$ for studying the product's shelf life and other quality attributes.

Moisture, crudes protein, ether extract and total ash were estimated as per AOAC (1984). The $\mathrm{pH}$ value of the prepared pickle was determined by using a digital $\mathrm{pH}$ Meter (Systronics, Model 335) and by following the method as described by Pippen et al., while the TBA value (mg malanoldehyde/ $\mathrm{kg}$ ) of the product was determined by using a Lomb and Bousch Spectrophotometer at $530 \mathrm{~nm}$ following the standard method as described by Witte et al., (1970).

The Total viable count and yeast and mould counts of ready-to-eat and shelf stable pickles were determined as described by Harrigan and McCancy and the results were expressed as $\log$ cfu (colony forming unit) per $g$ of meat. Standard plate count agar (Make: HiMedia, Code- M091) and Rose Bengal Chloramphenicol Agar (Make: HiMedia, Code- M640) were used for total viable count (TVC) and yeast and moulds count (YMC) respectively.

The sensory evaluations were conducted using an 8 - point descriptive scale (Keeton et al., 1984) where 8 denoted 'extremely desirable' and 1 denoted 'extremely poor'. A sensory panel (semi-trained) of six judges drawn from post-graduate, Ph.D. students of departments of Faculty of Veterinary and Animal Sciences, WBUAFS, Belgachia,
Kolkata was requested to evaluate the product for different quality attributes. All the spent duck, chicken and turkey meat pickles were evaluated for the above mentioned quality attributes at 30 days intervals and up to 90 days of storage at room temperature.

All the data obtained in the present investigation were analyzed statistically to draw a valid conclusion by using SPSS-20® software. Six replicates were performed for each experiment. The results were expressed as mean and standard error (SE) of mean. The means were analyzed by using Two-way ANOVA (for storage parameters) and means were compared using Tukey's HSD Post-Hoc test at 5\% level of significance in a SPSS-20® software package.

\section{Results and Discussion}

The results of the present study are presented in following table no. 2, 3 and 4. Average cooking yield of duck, chicken and turkey meat pickle were $59.1 \%, 57.2 \%$ and $58.8 \%$ respectively. The mean percentage of moisture, crude protein, ether extract and total ash contents of duck pickles were 36.18, $17.82,39.64$, and 3.71 respectively. The mean per cent moisture, crude protein, ether extract and total ash contents of chicken pickles were 59.74, 18.56, 15.92, and 3.51 respectively. The mean of per cent moisture, crude protein, ether extract and total ash contents of turkey pickles were $61.78,16.02,16.74$, and 3.28 respectively. These observations were in close agreement with the reports of Kangarajju and Subramanian (2012) in vinegar based duck meat pickle and also similar with the reports of Anna and Sobana (2020) in turkey meat pickle and das et al., (2013) in spent chicken meat pickle at room temperature.

The mean values for changes in physicchemical characteristics of spent duck, chicken and turkey meat pickle during room 
temperature storage are presented in Table 2. The $\mathrm{pH}$ values of duck, chicken and turkey meat pickle decreased significantly $(\mathrm{P}<0.05)$ with increasing storage period and which was below 5.0, that is considered to be critical for storage stability of pickled meat products (Dziezak, 1986). Sachdev et al., (1994) reported that $\mathrm{pH}$ of chicken meat pickle decreased significantly $(\mathrm{P}<0.01)$ from 20th day. TBA values of duck, chicken and turkey meat pickle were increased significantly $(\mathrm{p}<0.05)$ with increasing storage period. The present finding is in conformity with (Wastt, 1962). Increase in TBA values might be due to increase the production of volatile metabolites due to lipid oxidationin aerobic packaging. Increases in TBA values during storage period of various meat pickle were also reported earlier by Das et al., (2012), Maiti et al., (2009) and Pal and Agnihotri (1994).

The mean values for changes in microbiological characteristics of duck, chicken and turkey meat pickle at room temperature during storage are presented in
Table 3.Total viable counts and yeast and mould counts were increased significantly with increasing storage period and total viable counts were also differ between species meat pickle (Jay, 1996).Coliform spp., Salmonella spp., Clostridium spp. counts and staphylococcal counts were not detected throughout entire storage period up to 90 days. Throughout entire storage period, pathogenic microorganisms were not detected. This might be due to the heat treatment during cooking and addition of vinegar used for pickling that lead to retardation of microbial growth (Wani and Majeed, 2014). Yeast and mould counts were not detected between day 0 to 30 of storage thereafter yeast and mould counts were detected on $60^{\text {th }}$ day of storage. The microbial characteristics were reported in the present study were remained satisfactory up to 90 days of storage at room temperature. Similar observations were also recorded by Kumar and Bachil (1993) in pork pickle, Pal and Agnihotri (1994) in chevon meat pickle and Jayanthi et al., (2008) in spent hen meat pickle.

Table.1 Recipe of spices mixture used in the chicken pickle as per Das et al., (2013) with some modifications

\begin{tabular}{|l|l|c|}
\hline $\begin{array}{l}\text { Sl. } \\
\text { No }\end{array}$ & Ingredients & $\begin{array}{c}\text { Percent } \\
\text { (on fresh meat weight) }\end{array}$ \\
\hline $\mathbf{1 .}$ & Onion & 28.00 \\
\hline $\mathbf{2 .}$ & Ginger & 4.20 \\
\hline $\mathbf{3 .}$ & Garlic & 4.30 \\
\hline $\mathbf{4 .}$ & Commercial Chicken Masala & 1.00 \\
\hline $\mathbf{5 .}$ & Common Salt & 2.5 \\
\hline $\mathbf{6 .}$ & Cardamom Powder & 0.17 \\
\hline $\mathbf{7 .}$ & Clove Powder & 0.11 \\
\hline $\mathbf{8 .}$ & Cinnamon Powder & 0.17 \\
\hline $\mathbf{9 .}$ & Black Pepper Powder & 0.12 \\
\hline $\mathbf{1 0 .}$ & Cumin Powder & 0.55 \\
\hline $\mathbf{1 1 .}$ & Coriander Powder & 0.55 \\
\hline $\mathbf{1 2 .}$ & Turmeric Powder & 0.45 \\
\hline $\mathbf{1 3}$. & Chili Powder & 1.10 \\
\hline $\mathbf{1 4}$ & Vinegar & 3 \\
\hline & & \\
\hline
\end{tabular}


Table.2 Changes in physic-chemical characteristics of spent duck, chicken and turkey meat pickle during storage period at room temperature

\begin{tabular}{|c|c|c|c|c|c|c|c|c|c|c|c|c|}
\hline \multirow[b]{3}{*}{ Parameters } & \multicolumn{12}{|c|}{ Storage periods in Days } \\
\hline & \multicolumn{3}{|c|}{0 Day } & \multicolumn{3}{|c|}{$30^{\text {th }}$ Day } & \multicolumn{3}{|c|}{$60^{\text {th }}$ Day } & \multicolumn{3}{|c|}{$90^{\text {th }}$ Day } \\
\hline & $\begin{array}{c}\text { Duck } \\
\text { Pickle }\end{array}$ & $\begin{array}{c}\text { Chicken } \\
\text { Pickle }\end{array}$ & $\begin{array}{l}\text { Turkey } \\
\text { Pickle }\end{array}$ & $\begin{array}{c}\text { Duck } \\
\text { Pickle }\end{array}$ & $\begin{array}{c}\text { Chicken } \\
\text { Pickle }\end{array}$ & $\begin{array}{l}\text { Turkey } \\
\text { Pickle }\end{array}$ & $\begin{array}{l}\text { Duck } \\
\text { Pickle }\end{array}$ & $\begin{array}{c}\text { Chicken } \\
\text { Pickle }\end{array}$ & $\begin{array}{l}\text { Turkey } \\
\text { Pickle }\end{array}$ & $\begin{array}{c}\text { Duck } \\
\text { Pickle }\end{array}$ & $\begin{array}{c}\text { Chicken } \\
\text { Pickle }\end{array}$ & $\begin{array}{l}\text { Turkey } \\
\text { Pickle }\end{array}$ \\
\hline pH & $\begin{array}{c}4.74 \pm 0.0 \\
1^{\mathrm{ax}}\end{array}$ & $\begin{array}{c}4.67 \pm 0.0 \\
2^{\text {ay }}\end{array}$ & $\begin{array}{c}4.72 \pm 0.0 \\
3^{\mathrm{ax}}\end{array}$ & $\begin{array}{c}4.66 \pm 0.0 \\
2^{\text {bx }}\end{array}$ & $\begin{array}{c}4.59 \pm 0.0 \\
2^{\text {by }}\end{array}$ & $\begin{array}{c}4.62 \pm 0.0 \\
0^{\mathrm{bx}}\end{array}$ & $\begin{array}{c}4.57 \pm 0.0 \\
1^{\mathrm{cx}}\end{array}$ & $\begin{array}{c}4.48 \pm 0.0 \\
2^{\text {cy }}\end{array}$ & $\begin{array}{c}4.54 \pm 0.0 \\
2^{\mathrm{cx}}\end{array}$ & $\begin{array}{c}4.44 \pm 0.0 \\
1^{\mathrm{dx}}\end{array}$ & $\begin{array}{c}4.39 \pm 0.0 \\
2^{\mathrm{dy}}\end{array}$ & $\begin{array}{c}4.48 \pm 0.0 \\
1^{\mathrm{dx}}\end{array}$ \\
\hline $\begin{array}{l}\text { TBA (mg } \\
\text { malonaldehy } \\
\text { de/kg) }\end{array}$ & $\begin{array}{c}0.668 \pm 0 \\
002^{\mathrm{ax}}\end{array}$ & $\begin{array}{c}0.554 \pm 0 \\
002^{\text {ay }}\end{array}$ & $\begin{array}{c}0.661 \pm 0 \\
006^{\mathrm{ax}}\end{array}$ & $\begin{array}{c}0.779 \pm 0 \\
001^{\mathrm{bx}}\end{array}$ & $\begin{array}{c}0.655 \pm 0 \\
005^{\text {by }}\end{array}$ & $\begin{array}{c}0.765 \pm 0 \\
005^{\mathrm{bx}}\end{array}$ & $\begin{array}{c}0.887 \pm 0 \\
002^{\mathrm{cx}}\end{array}$ & $\begin{array}{c}0.754 \pm 0 \\
004^{\mathrm{cy}}\end{array}$ & $\begin{array}{c}0.863 \pm 0 \\
006^{\mathrm{cx}}\end{array}$ & $\begin{array}{c}0.949 \pm 0 \\
012^{\mathrm{dx}}\end{array}$ & $\begin{array}{c}0.900 \pm 0 \\
007^{\mathrm{dy}}\end{array}$ & $\begin{array}{c}0.959 \pm 0 \\
006^{\mathrm{dx}}\end{array}$ \\
\hline
\end{tabular}

* Interaction means bearing different superscripts between storage days within rows (a, b, c, d) differ significantly $(\mathrm{P}<0.05)$

** Interaction means bearing different superscripts between species within rows $(\mathrm{x}, \mathrm{y}, \mathrm{z})$ differ significantly $(\mathrm{P}<0.05)$

Table.3 Changes in microbial quality of shelf stable spent duck, chicken and turkey meat pickle during storage period at ambient temperature (Storage periods in days, microbial counts in log values)

\begin{tabular}{|c|c|c|c|c|c|c|c|c|c|c|c|c|}
\hline \multirow[b]{3}{*}{ Parameters } & \multicolumn{12}{|c|}{ Storage Days } \\
\hline & \multicolumn{3}{|c|}{0 Day } & \multicolumn{3}{|c|}{$30^{\text {th }}$ Day } & \multicolumn{3}{|c|}{$60^{\text {th }}$ Day } & \multicolumn{3}{|c|}{$90^{\text {th }}$ Day } \\
\hline & $\begin{array}{l}\text { Duck } \\
\text { Pickle }\end{array}$ & $\begin{array}{l}\text { Chicken } \\
\text { Pickle }\end{array}$ & $\begin{array}{l}\text { Turkey } \\
\text { Pickle }\end{array}$ & $\begin{array}{l}\text { Duck } \\
\text { Pickle }\end{array}$ & $\begin{array}{l}\text { Chicken } \\
\text { Pickle }\end{array}$ & $\begin{array}{l}\text { Turkey } \\
\text { Pickle }\end{array}$ & $\begin{array}{l}\text { Duck } \\
\text { Pickle }\end{array}$ & $\begin{array}{l}\text { Chicken } \\
\text { Pickle }\end{array}$ & $\begin{array}{l}\text { Turkey } \\
\text { Pickle }\end{array}$ & $\begin{array}{c}\text { Duck } \\
\text { Pickle }\end{array}$ & $\begin{array}{l}\text { Chicken } \\
\text { Pickle }\end{array}$ & $\begin{array}{l}\text { Turkey } \\
\text { Pickle }\end{array}$ \\
\hline $\begin{array}{l}\text { Total Viable } \\
\text { Count }\end{array}$ & $2.57 \pm 0.06^{\mathrm{ax}}$ & $2.42 \pm 0.04^{\mathrm{axy}}$ & $2.39 \pm 0.04^{\mathrm{ay}}$ & $2.89 \pm 0.06^{\mathrm{bx}}$ & $2.78 \pm 0.04^{\text {bxy }}$ & $2.69 \pm 0.04^{\text {by }}$ & $3.52 \pm 0.07^{\mathrm{cx}}$ & $3.57 \pm 0.04^{\mathrm{cxy}}$ & $3.43 \pm 0.08^{\mathrm{cy}}$ & $4.47 \pm 0.06^{\mathrm{dx}}$ & $4.41 \pm 0.07^{\mathrm{dxy}}$ & $4.34 \pm 0.08^{\mathrm{dy}}$ \\
\hline $\begin{array}{l}\text { Salmonella spp. } \\
\text { Count }\end{array}$ & Nil & Nil & Nil & Nil & Nil & Nil & Nil & Nil & Nil & Nil & Nil & Nil \\
\hline $\begin{array}{l}\text { Yeast \& Mould } \\
\text { Count }\end{array}$ & Nil & Nil & Nil & Nil & Nil & Nil & $2.39 \pm 0.07^{\mathrm{ax}}$ & $2.44 \pm 0.05^{\mathrm{ax}}$ & $2.38 \pm 0.05^{\mathrm{ax}}$ & $2.67 \pm 0.03^{\mathrm{bx}}$ & $2.65 \pm 0.03^{b x}$ & $2.62 \pm 0.05^{\mathrm{bx}}$ \\
\hline $\begin{array}{l}\text { Coliforms } \\
\text { Count }\end{array}$ & Nil & Nil & Nil & Nil & Nil & Nil & Nil & Nil & Nil & Nil & Nil & Nil \\
\hline $\begin{array}{l}\text { Staphylococcous } \\
\text { spp. Count }\end{array}$ & Nil & Nil & Nil & Nil & Nil & Nil & Nil & Nil & Nil & Nil & Nil & Nil \\
\hline $\begin{array}{l}\text { Clostridium } \\
\text { spp. Count }\end{array}$ & Nil & Nil & Nil & Nil & Nil & Nil & Nil & Nil & Nil & Nil & Nil & Nil \\
\hline
\end{tabular}

* Interaction means bearing different superscripts between storage days within rows (a, b, c, d) differ significantly $(\mathrm{P}<0.05)$

** Interaction means bearing different superscripts between species within rows $(\mathrm{x}, \mathrm{y}, \mathrm{z})$ differ significantly $(\mathrm{P}<0.05)$ 
Table.4 Changes in organoleptic qualities of spent duck, chicken and turkey meat pickle during storage periods at room temperature

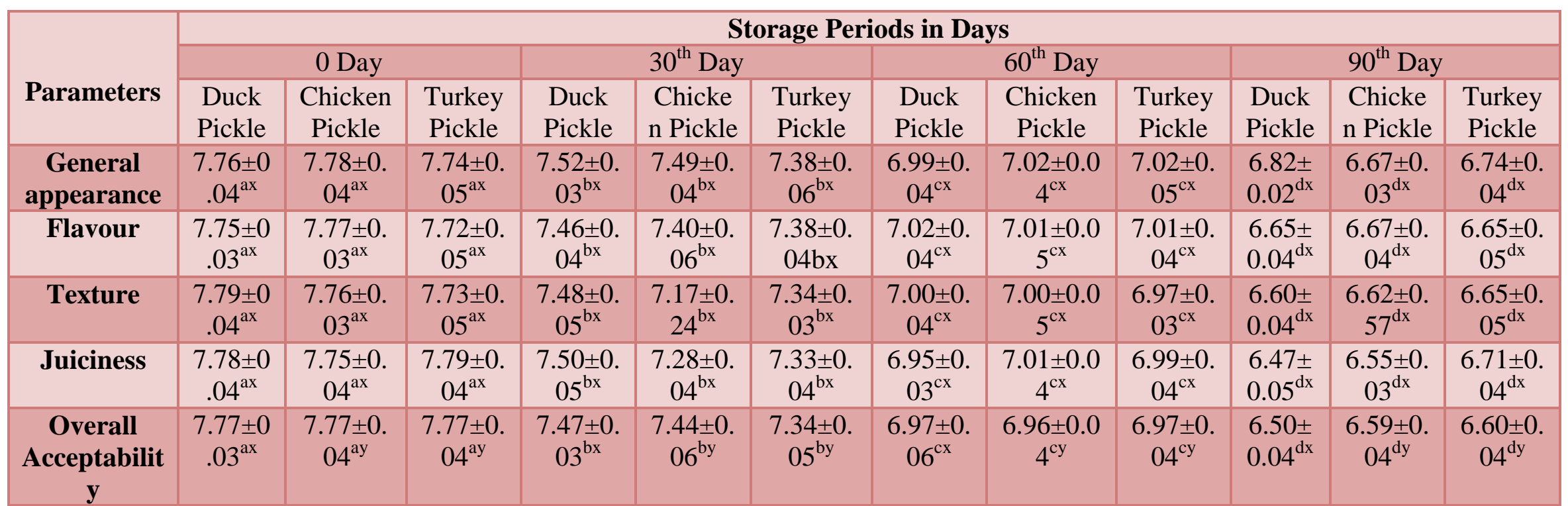

* Interaction means bearing different superscripts between storage days within rows $(\mathrm{a}, \mathrm{b}, \mathrm{c}, \mathrm{d})$ differ significantly $(\mathrm{P}<0.05)$.

** Interaction means bearing different superscripts between species within rows $(\mathrm{x}, \mathrm{y}, \mathrm{z})$ differ significantly $(\mathrm{P}<0.05)$. 
The mean values for changes in sensory attributes of duck, chicken and turkey meat pickle during room temperature storage are presented in Table 4. A significantly gradual decline in sensory attributes such as general appearance, flavour, texture, juiciness and overall acceptability was observed during the entire storage period up to 90 days. Sensory evaluation of various species meat pickles showed that spent duck, hen and turkey meat pickle was acceptable even at the end of 90 days storage at ambient temperature. These observations were in close agreement with the reports of Kangarajju and Subramanian (2012) in vinegar based duck meat pickle. These observations were also closely similar to those observed by khanna et al., (2004) in bone-in meat pickle from spent hen and also agrrement with observation of Das et al (2007) in goat meat pickle. A decrease in flavour scores along with increase the storage period was also studied by Sen and Karim (2003) in rabbit meat pickle. The significant decrease in flavour scores on prolonged storage period at room temperature might be due to the corresponding increase in TBA values of the meat products.

Similar observations of decrease in overall acceptability of pickle with increasing storage period in various meat pickles were also studied by (Pal and Agnihotri (1994), Janathi et al., (2008). As, the results obtained from the present study of physico-chemical, microbiological and organoleptic evaluation, it may be stated that vinegar based spent duck, hen and turkey meat pickle acceptable to the local consumers and storage stability up to 90 days at ambient temperature. This is also opened a gateway of entrepreneurial opportunity for the unemployment youth, rural poor villagers, marginal poultry farmers, self-help groups and especially rural women folk to take up this opportunity as a source of additional income.

\section{Acknowledgement}

Authors are highly thankful to Department of Livestock Products Technology, WBUAFS, Kolkata, West Bengal for providing research oriented environment for successful completion of this work.

\section{References}

20th Livestock Census Report, 2019, Ministry of Fisheries, Animal Husbandry \& Dairying, Govt. of India

Anjayeyulu, A. S. R. 2005. Hurdle Technology for Shelf stable meat products. In: Recent advances in poultry and egg processing quality assessment of Poultry products- short term training course, pp: 63-68, C. A.R.I. Izatnagar, Bereilly (U.P.)

Anna Anandh. M. and Sobana. A. S. 2020. Storage Quality and Acceptability of Turkey Meat Pickle at Room Temperature $\quad\left(32 \pm \quad \pm \quad 5^{\circ} \mathrm{C}\right)$. Int.J.Curr.Microbiol.App.Sci. $\quad 9(05)$ : 346-352.

AOAC. 1984. Official Methods of Analysis. 16th edn. Association of official Analytical Chemists, Will behington, D.C.

Biswas, S., Banerjee, R., Bhattacharyya, D., Patra, G., Das, A. K., \& Das, S. K. 2019. Technological investigation into duck meat and its products-a potential alternative to chicken. World's Poultry Science Journal, 75(4), 609-620.

Chatterjee, R.N. and Rajkumar, U. 2015. An overview of poultry Production in India. Indian Journal of Animal Health. 54(2): 89-108

Das A, Nath D.R, Hazarika M and Laskar S.K. 2013. Studies on certain quality attributes of meat pickle prepared from spent chicken, Vet World 6(3):156158.

Das, A K., Sharma, R. B. and Singh, N. P. 
2007 Quality and Storage Stability of Low Acid Goat Meat Pickle. American J. Food Technol., 2(6): 550-554.

Das, A., Nath,D.R., Hazarika, M. andLaskar, S.K. 2012. Studies on certain quality attributes of meat pickle prepared from spent chicken, Veterinary World, 6:156 $-158$.

Dziezak, J. D. 1986. Antioxidants and antimicrobial agents. Food Technology, 40: 94 - 111.

Guleria, P., Kumari, S., Khan, A. and Dangi, N. 2015.Present Scenario of Indian Meat Industry-A Review.International Journal of Enhanced Research in Science, Technology \& Engineering. 4(9): 251-257

Jay, J.M. 1996. In: Modern food microbiology, 4th edn. CBS publishers and distributors, New Delhi, India.

Jayanthi, D., Karthik, P., Kulkarni,V.V., Arthanarieswaran, M., Kanagarajau, P. and Chandirasekaran, V. 2008. Development of traditional styled meat pickle from spent hen meat. Journal of Meat Science, 5:11 - 14.

Kanagaraju, P. and Subramanian, A. 2012.Preparation of Spent Duck Meat Pickle and its Storage Studies at Room Conclusion Temperature. American J. Food Technol. 7(1): 29-33.

Keeton, J. T., Foegeding, E.A. and Patina, A.C. 1984. A comparison pf non meat products, sodium tripolyphosphate and processing temperature effects on physical and sensory properties of frank furthers. J.Food Sci. 49: 14621474.

Khanna, N., Sharma, D. P., Ahlawat, S. S. and Sahoo, J. 2004. Shelf stable bone in meat pickle from spent hen. J. Food Sci. Technol., 41: 445- 447.

Kumar, V. and Bachhil, V. N. 1993. Studies on development and keeping quality of pork pickle: Effect of different preservatives on its quality and shelf life. Indian Food Packer, 47: 15 - 21.

Maiti, A.K., Ahlawat, S.S. and Khanna. N. 2009.Studies on Development of Tenderized Chicken Gizzard and Goat Heart Pickles. Indian J. Anim. Res., 43 (4): 255-258.

MFAHD (2019).20th Livestock Census Report. 2019.All India Report published by Ministry of Fisheries, Animal Husbandry \& Dairying, Department of Animal Husbandry \& Dairying, Animal Husbandry Statistics Division, 234-Krishi Bhawan, New Delhi-110001, Government of India. www.dahd.nic.in

Pal, U.K. and Agnihotri, M.K. 1994. Storage stability of chevon pickle at room temperature. Journal of Applied Animal Research, 5:89 - 93.

Sachdev, A.K., Ram Gopal, Verma, S.S., Kapoor, K.N. and Kulshreshtha, S.B. 1994). Quality of chicken Gizzard pickle during processing and storage. Journal of Food Science and Technology, 31: 32-35.

Sahoo, J., \& Panda, P. C. 1983.Effect of different scalding techniques on dressing yield of chicken and duck.Indian journal of poultry science.

Sen, A. R. and Karim, S. A. 2003. Storage stability of rabbit pickle at room temperature. J. Food Sci. Technol., 40:197-200.

Staff, C.E. and Darrow, M.I. 1953.Poultry Science, 32, 145. Cited by: Sahoo ,J. (1983). Influence of sex on meaty cut up parts of desi duck carcasses in Kashmir. Indian Journal of meat Science \& Technology, 3(1): 87-91.

Sumarmono, J. 2019. Duck production for food security. In IOP Conference Series: Earth and Environmental Science (Vol. 372, No. 1, p. 012070). IOP Publishing.

Wani, S. A., \&Majeed, D. 2014. Evaluation of quality attributes and storage 
stability of pickle prepared from chicken gizzard. Journal of Meat Science and Technology, 2(4): 85-89.

Wastt, B.M. 1962. Meat products.In : Symposium on food lipids and their oxidation. AVI Publishing Co.Inc.,
Westport CT.

Witte, V. G., Krause, G. F. and Barley, M. E. 1970.A new extraction method for 2 thiobarbituric acid value for pork and beef during storage. J. Food Sci., 35:582 -583.

\section{How to cite this article:}

Abadhut Dey, Saurabh Karunamay, Subhasish Biswas, Debasish Bhattacharya, Gopal Patra and Sudip Kumar Das. 2021. Comparative Study of the Shelf Life of Ready to Eat and Shelf Stable Meat Pickle Prepared from Spent Duck, Chicken and Turkey Meat. Int.J.Curr.Microbiol.App.Sci. 10(01): 2102-2110. doi: https://doi.org/10.20546/ijcmas.2021.1001.242 